\title{
Snowpack ablation and associated processes in the Subarctic forest near Fort Norman, N.W.T., Canada
}

\author{
G. Peter Kershaw \\ Department of Geography, University of Alberta, Edmonton, Alberta, Canada T6G 2H4
}

\begin{abstract}
An experiment was established to measure the rate of snowpack ablation and associated processes within a Subarctic upland forest. Two areas were studied: a linear clearing and an adjacent undisturbed forest. Lysimeter readings were taken at least twice daily over about a 5 d period as the snowpack ablated from approximately $90 \%$ of mid-winter values $(\mathrm{ca} 70 \mathrm{~cm}$ ). The lysimeter number declined from a total for both areas of 178 to 15 when the study was terminated due to insufficient snow cover. Ground surface and air temperatures as well as wind speed were recorded during the study period. In addition, runoff within the cleared area was monitored. Ablation occurred most rapidly and was complete first on the cleared right-of-way. This was facilitated by thinner snowpack, warmer temperatures and higher wind speeds than in the undisturbed forest. Little ground storage of meltwater occurred until the second day of the study when subsurface (throughflow) movement of water was measured. At this time the active layer was melting and water was infiltrating the soil. The majority of snowmelt became runoff from the site. Evaporation and sublimation losses from the snowpack were small.
\end{abstract}

KEY WORDS: Snow melt - Snow runoff · Spring thaw - Snowpack ablation - Subarctic snowmelt

\section{INTRODUCTION}

Studies of Subarctic environments have included investigations of snowpack characteristics. In the Schefferville (Quebec, Canada) area there have been several studies concerned with the distribution of snow (Adams \& Findlay 1966, Adams \& Rogerson 1968). These Subarctic environments have highly variable snowpacks which reflect the environment of deposition and redistribution by wind.

Studies conducted in the High Arctic to monitor snowmelt processes (Lewkowicz \& French 1982, Woo et al. 1982) indicate that substantial quantities of snowmelt water may percolate through the snowpack. Much of snowmelt water may infiltrate the active layer to become thaw layer storage but this will occur only as the thaw layer develops and the potential for absorption results (Lewkowicz \& French 1982).

In British Columbia, Jordan (1983) monitored snowmelt and discharge in a 4 ha drainage basin in the mountainous headwaters of the Bridge River-Seton River. The site had a 10 to $20^{\circ}$ slope with a tree cover of $3 \%$. Snowpack was deep, in excess of $1.4 \mathrm{~m}$. Jordan monitored solar radiation, lysimeter discharge and stream discharge over a $20 \mathrm{~d}$ period commencing late June.

Snowpack ablation includes several components in the annual disintegration of the winter snowpackevaporation, sublimation and melt. Snowpack meltwater initially percolates into the snowpack and then can be absorbed into the surface soil horizons, temporarily stored at the surface or become runoff from the site.

The objective of the study was to determine the impact of a cleared transport corridor on the temporal and spatial characteristics of snowmelt within a Subarctic upland forest. This included the measurement of relationships among air temperature, snowpack ablation, snowmelt water runoff and on-site storage.

\section{STUDY AREA}

The study was conducted at the Studies of the Environmental Effects of Disturbances in the Subarctic (SEEDS) facility $10 \mathrm{~km}$ north of Fort Norman, N.W.T., Canada. The research area was approximately 4 ha with the experiment confined to 0.4 ha of cleared right- 
of-way (ROW) and 1.1 ha of undisturbed forest adjacent to the ROW (Fig. 1). The cleared simulated transport corridor was $25 \mathrm{~m}$ wide and included a backfilled simulated buried pipeline trench ( $2 \mathrm{~m}$ wide). The surface vegetation, dominated by mosses and lichens, was left intact on the ROW but, as a result of trenching, the simulated buried pipeline trench surface was mineraldominated with a graminoid cover. The overstorey in the forest was dominated by black spruce Picea mariana composing about a $15 \%$ canopy cover. The shape of the installation was designed to fit the $630 \mathrm{~m}$ corri- dor into the 4 ha site. The SEEDS facility was established in 1985 and has been the subject of a number of investigations since then.

\section{METHODS}

Microclimate. Dataloggers were installed to monitor microclimate on the cleared ROW, the simulated pipeline trench and in the undisturbed forest. Due to instrument failure no microclimate data were available

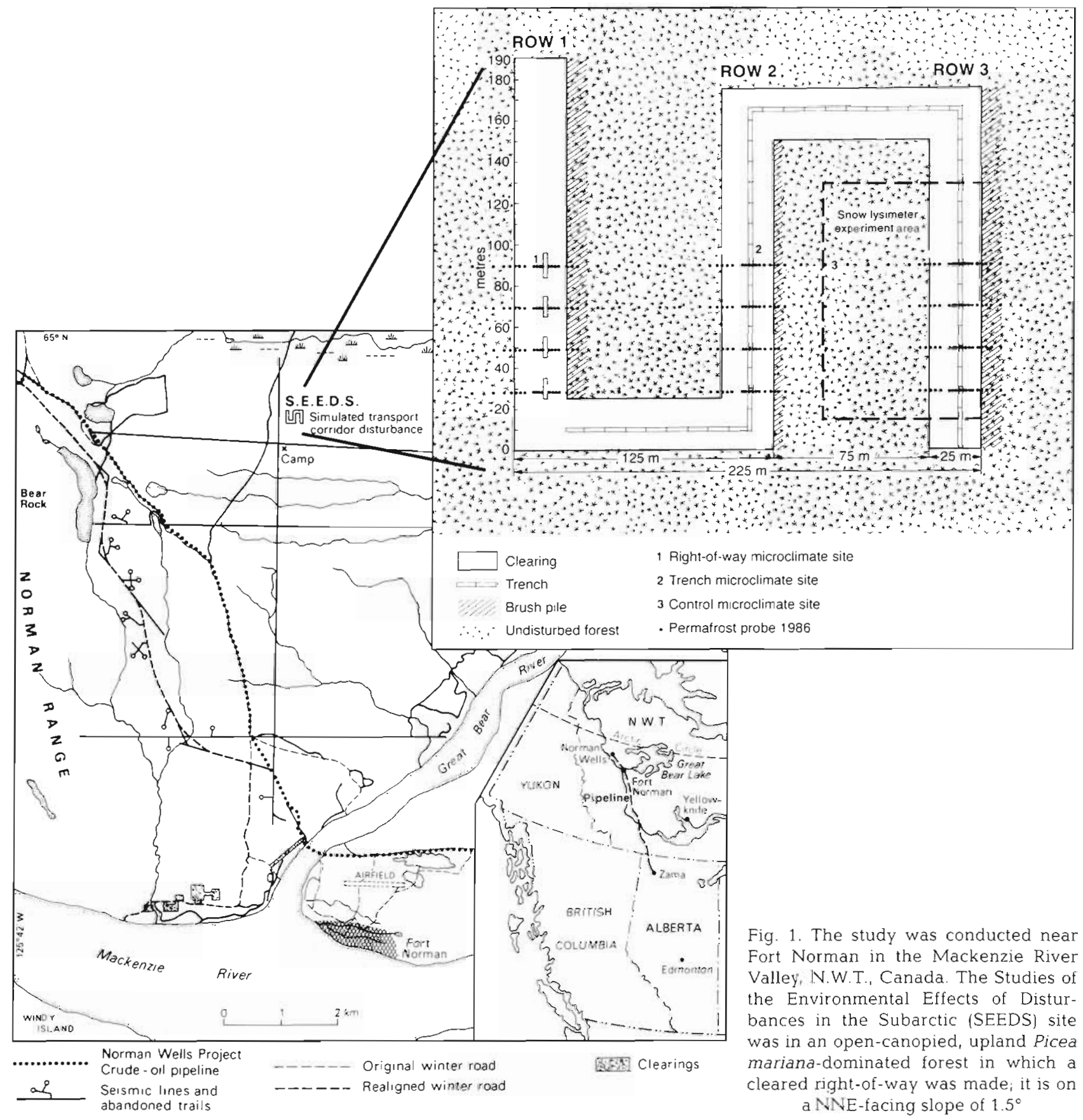


for the period immediately prior to 4 May 1991. Mean daily values were derived from data collected on a 1 min scan interval. Most significant to this study were the temperatures, measured with thermocouples, for the ground surface and air. Thawing-degree-day totals were calculated from the mean daily data. The primary purpose for the dataloggers was to monitor microclimate conditions associated with a number of revegetation treatments on the trench and consequently the number of surface temperature sensors on the trench was 18 while in the undisturbed forest there were 5, and only 1 site on the cleared ROW was monitored. Air temperatures (i.e. at $+10 \mathrm{~cm},+50 \mathrm{~cm}$ and $+150 \mathrm{~cm}$ ) were recorded above the trench, the ROW and at 2 sites in the forest. Early in the experiment the 10 and $50 \mathrm{~cm}$ sensors were within the snowpack but were exposed as snowmelt proceeded. Ground surface temperatures were recorded with the thermocouple sufficiently imbedded within the surface moss, lichen or litter layer to provide shielding (usually within $1 \mathrm{~cm}$ of the air). In order to insure comparability of results only the ground surface data from the sites with air temperature records have been used in the analysis

Depth of thaw. There were 4 parallel sampling transects crossing the site, each consisting of 91 permanent sample points (Gallinger \& Kershaw 1988). On each transect there were 29 points that fell within the 1.5 ha area of the ablation study $(\mathrm{n}=116)$. A metal rod $(0.95 \mathrm{~cm}$ diameter) was forced into the soil to the point at which further penetration was prevented by the frozen soil. The depth of thaw was recorded in this manner on 8 and 15 May, during and shortly after snowmelt.

Snowpack ablation. Commercially available styrofoam cups (6.7 cmiameter at the mouth, tapering to $4.0 \mathrm{~cm}$ at the base and $8.5 \mathrm{~cm}$ high, for approximately $190 \mathrm{ml}$ volume) were used to contain the snow, a technique employed by Lewkowicz \& French (1982). These empty lysimeters averaged $2.06 \mathrm{~g}(\mathrm{n}=178, \mathrm{SD}=0.117)$, offered little heat sink capabilities (white with low heat conductance), and were inexpensive and easily obtainable in large quantities. Two cups were deployed at each of the 49 sample sites in the forest and at the 40 sites on the cleared ROW for a total of 89 sites or 178 lysimeters. One of the individually numbered and weighed cups at each sample site was perforated to permit meltwater to drain.

The cups were filled with snow by simply scooping it in and then they were pushed into the snowpack until the opening was flush with the undisturbed snow surface. Both cups were placed about $20 \mathrm{~cm}$ apart at randomly determined sites. At the time of the initiation of the project there was about $50 \%$ snow cover on the ROW and $95 \%$ in the forest. Consequently, deployment of cups was not totally random since a minimum distance to bare ground of $75 \mathrm{~cm}$ was required. As the experiment continued cups may have been moved as much as $2 \mathrm{~m}$ to keep them within the ever decreasing snowpack. As weight was lost cups were refilled once they dropped below $20 \mathrm{~g}$ Full cups ranged in weight from 60 to $100 \mathrm{~g}$ approximately or 315.8 to $526.3 \mathrm{~kg}$ $\mathrm{m}^{-3}$. Below this range the cups were removed and consequently the sample number declined through the study period. As the experiment progressed fewer lysimeters could be placed in snow areas and the sample size declined rapidly in the ROW and more gradually in the forest. Thus sample size changed for ROW and forest, respectively, from 89 and 90 on 4 May to 6 and 33 on 9 May. Cups did melt out completely and tip between readings and these were also lost from the sample number. In an effort to minimize loss of data, the network was checked at least twice daily and as frequently as 6 times in a 24 h period.

Weighing was conducted with an Ohaus portable scale capable of measuring to $0.05 \mathrm{~g}$. The weight loss was calculated by dividing the weight change by the time interval between readings. Due to the shape of the cup, the surface area changed as the snow level dropped. At the top the area would be $35.5 \mathrm{~cm}^{2}$ while half full it would be approximately $10 \mathrm{~cm}^{2}$ less. This reduced exchange surface area would reduce weight loss due to evaporation and sublimation. Additional effects would occur due to the cup lip protruding above the snowpack surface, and the volume loss in the cup would also produce a still air column between the cup lip and the changing level of the snow inside. Multiple visits during the melt period and the refilling of the lysimeters were precautions taken to reduce these sources of measurement error.

During 5 to 6 May a survey was conducted on an established snow course. There were 3 parallel transects crossing the site at $50 \mathrm{~m}$ intervals with sampling sites $10 \mathrm{~m}$ apart. A total of 114 sites were sampled with an Adirondack snow corer to determine depth and density of the snowpack. Of the 33 on the ROW, 3 had snow while 78 of the 81 in the forest had snow.

Runoff. An installation modelled after Steer \& Woo (1983) was constructed in February 1987. To capture subsurface throughflow, an $80 \mathrm{~cm}$ deep trench across the $2 \mathrm{~m}$ wide simulated pipeline trench was lined with a polyethylene sheet and then backfilled. Water moving down slope through the active layer was prevented from passing beyond the dam, forced to the surface and then channelled into a drain pipe so that it could be measured. To collect surface runoff a dam was constructed of plywood $3 \mathrm{~m}$ up slope of the subsurface dam. The surface dam was faced with polyethylene and an apron was extended $1.5 \mathrm{~m}$ up slope of the dam. The plywood was notched to permit the installation of a length of plastic rain gutter to drain the area above the dam. This gutter passed water over the lower, subsurface-flow dam. The 
principle was that surface runoff was removed and separated into one drain pipe while subsurface flow was trapped after the surface component was separated. On the adjacent ROW the subsurface dam was part of the above-ground dam and so both surface and subsurface water were combined in 1 drain pipe.

With high discharges, early in the snowmelt period the capacity of the rain gutter draining the surface runoff from the simulated pipeline trench could be exceeded. Furthermore, the $3 \mathrm{~m}$ length of the dam made it possible at these times for water to get around the obstruction during high discharges. However, since the subsurface dam was $3 \mathrm{~m}$ down slope it trapped this water and made it possible to measure it along with the subsurface component. Consequently in early spring during peak snowmelt, the surface component was under-measured while the subsurface values were correspondingly higher. Since at this time the soil remained frozen it was assumed that most of the subsurface discharge measured was surface runoff.

The discharge was measured by timing how long it took to fill a known volume $(4 \mathrm{l}, 1 \mathrm{l}$ or $250 \mathrm{ml})$. The readings were taken at approximately $3 \mathrm{~h}$ intervals during the day commencing midto late morning. Calculations of discharge were made in $l \mathrm{~s}^{-1}$ and then converted to a total $\left(\mathrm{m}^{3}\right)$ for the periods between readings. All values were means calculated from the 2 readings bracketing the time period. Similarly, the last reading of one day and the first of the next day were averaged to estimate the overnight value.
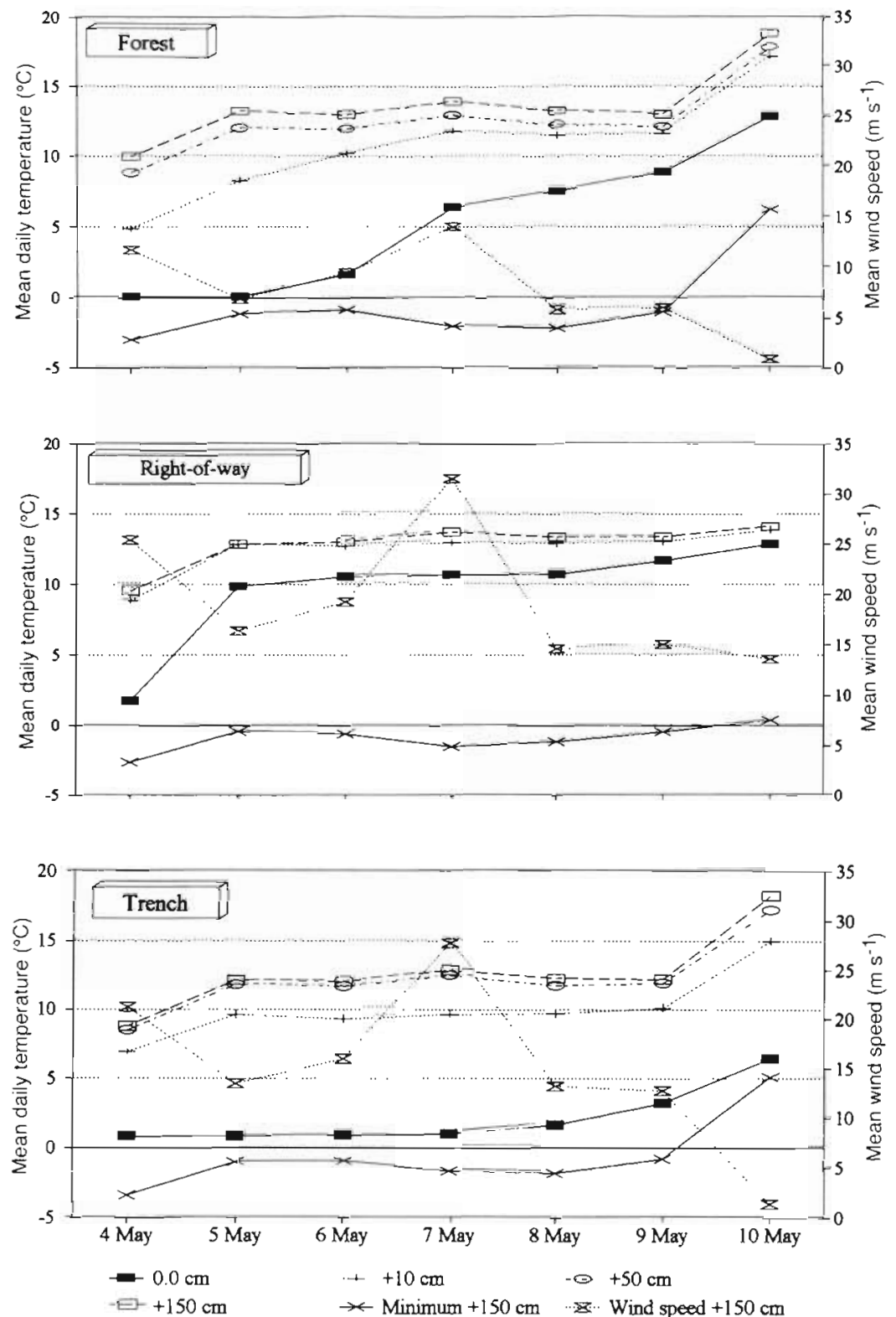

Fig. 2. Mean daily air and surface temperatures; minimum air temperatures; and wind speed at $1.5 \mathrm{~m}$ height during the snowmelt period (4 to 10 May 1991) at sites in the forest (control), cleared right-of-way (ROW) and simulated pipeline trench, SEEDS, Fort Norman, N.W.T., Canada

\section{RESULTS}

\section{Snowpack characteristics}

At the initiation of the study ablation of the snowpack was under way and approximately $50 \%$ of the ROW was exposed ground; about $25 \%$ of the trench was bare and only some qamaniq areas (i.e. thinner snowpack beneath a tree due to snow held on the tree canopy) were snow-free in the forest. Snow course val- ues for forest snowpack density averaged $337.8 \mathrm{~kg} \mathrm{~m}^{-3}$ $(\mathrm{n}=78, \mathrm{SD}=83.3$ ) while on the ROW only 3 of the sample sites had snow $\left(250,250\right.$ and $\left.393.9 \mathrm{~kg} \mathrm{~m}^{-3}\right)$. Mean snow depth in the lysimeter network on the ROW was $32.3 \mathrm{~cm}(\mathrm{n}=79, \mathrm{SD}=9.32)$ while in the forest it was $40.6 \mathrm{~cm}(\mathrm{n}=98, \mathrm{SD}=9.72)$. Initially lysimeters were placed at an average distance from bare ground of $83.9 \mathrm{~cm}(\mathrm{n}=79, \mathrm{SD}=40.5)$ and $83.3 \mathrm{~cm}(\mathrm{n}=98, \mathrm{SD}=$ 30.2) for ROW and forest respectively. Lysimeter snow density was not significantly different $(p<0.01)$ be- 
tween the ROW (415.1 $\mathrm{kg} \mathrm{m}^{-3} ; \mathrm{n}=79, \mathrm{SD}=44.2$ ) and the forest $\left(422.1 \mathrm{~kg} \mathrm{~m}^{-3} ; \mathrm{n}=98, \mathrm{SD}=47.7\right)$. These lysimeter values were higher than the mean densities from the snow course but were within the range of the snow course densities, which varied from 166.7 to $600 \mathrm{~kg} \mathrm{~m}^{-3}$. These high densities reflect the advanced nature of melt and the consolidation of the snowpack during spring melt.

\section{Microclimate}

Mean daily air temperatures at all heights in the forest, on the ROW and over the simulated pipeline trench were above $0^{\circ} \mathrm{C}$ for the study period (Fig. 2). Minimum daily temperatures were below freezing on all days except 10 May. The ground surface sensors at the trench site were essentially snow-free when the study began whereas the forest site had snowpack for the first $2 \mathrm{~d}$. Surface temperatures increased gradually on the trench while in the forest there was a distinct threshold step after snowmelt on 6-7 May when the temperature rose by approximately $5^{\circ} \mathrm{C}$. The 10 May increase in temperature for all sensors corresponded with a synoptic warming trend.

Compilation of thawing-degree-day totals for the 3 sites indicate that the ROW had much warmer temperatures at all heights (Fig. 3). This was most evident at the ground surface and $10 \mathrm{~cm}$ heights. The trench temperatures were coldest.

Wind speeds on the treeless ROW/trench were almost double the values for the forest at $1.5 \mathrm{~m}$ height

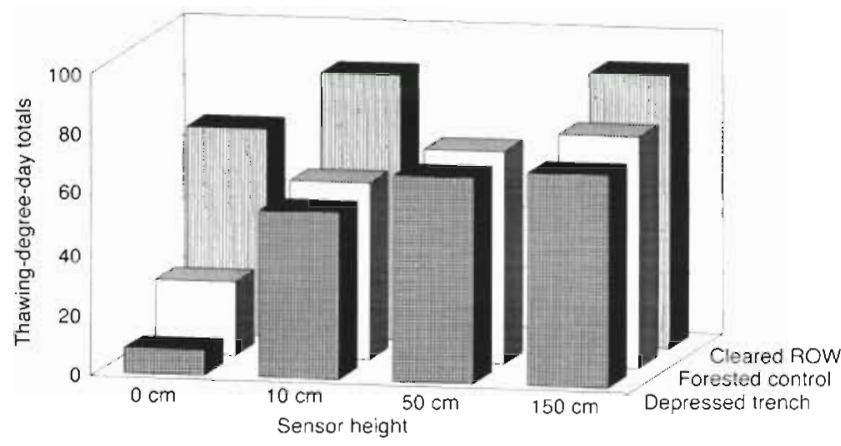

Fig. 3. Comparison of cleared ROW, forest (control) and simulated pipeline trench site thawing-degree-day totals $\left(>0^{\circ} \mathrm{C}\right)$ at various heights during snowmelt (4 to 9 May 1991)

(Fig. 2). The pattern of wind speed was similar for all sites with maximum values achieved in the middle of the study period. The values indicate that during the study period winds were strong. The high values associated with the ROW and trench reflect the lack of tree cover and its influence on wind speed (Fig. 2).

\section{Depth of thaw}

Thaw of the soil began about the time of snowpack dissipation. No data are available for pre-melt because the sample site flags were impossible to locate; however by 8 May maximum thaw was $25 \mathrm{~cm}$ with mean depths in the forest, on the ROW and trench of 11.2, 13.6 and $15.4 \mathrm{~cm}$ respectively (Fig. 4). The trench and area sur-
Fig. 4. Depth of thaw during (8 May, $\mathbf{4})$ and at the end (15 May, o) of the snowmelt period in the forest (control), on a cleared right-of-way and on a simulated pipeline trench, SEEDS, Fort Norman, N.W.T., Canada

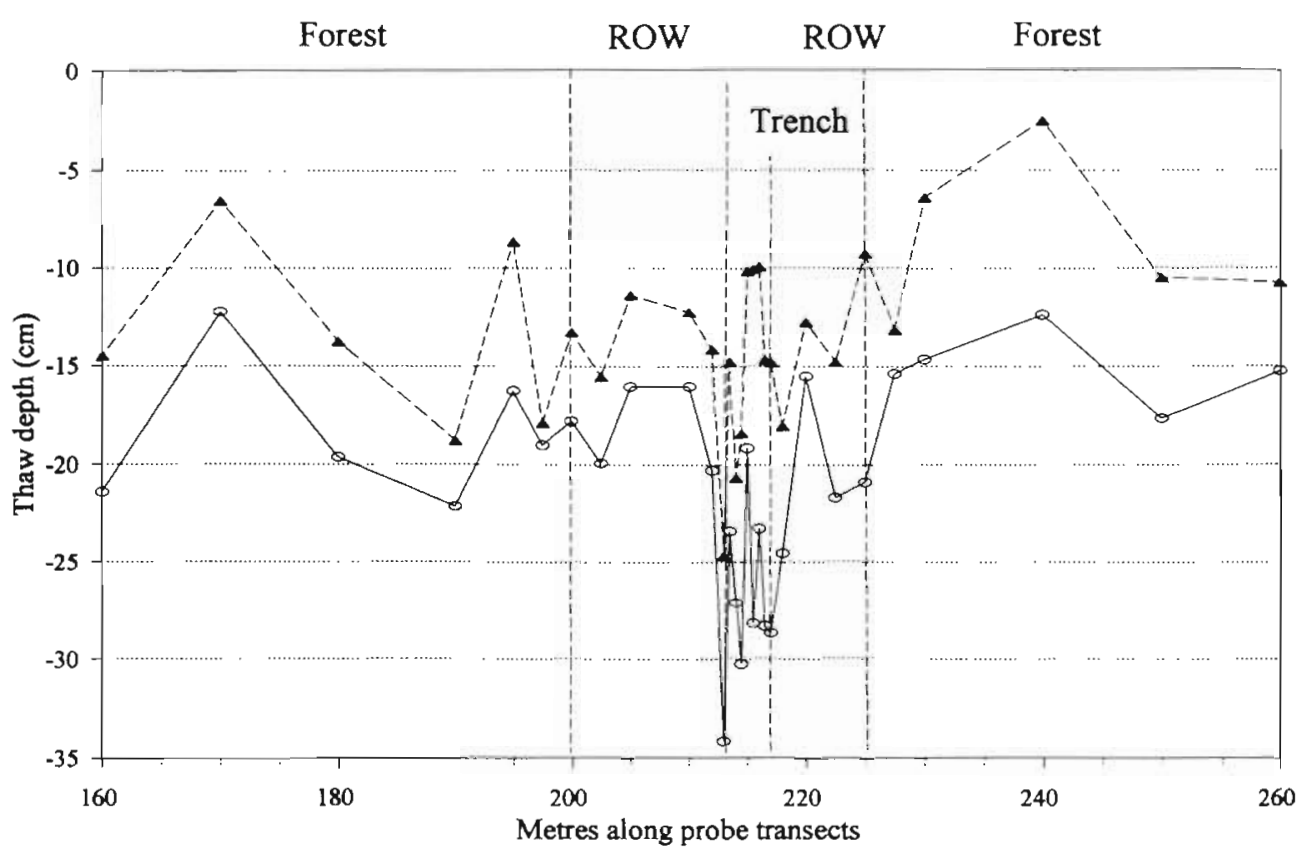


rounding it had the deepest thaw on both sample dates, with almost double the thaw in the forest on $15 \mathrm{May}$ (forest: $16.9 \mathrm{~cm}$, ROW: $20.1 \mathrm{~cm}$; trench: $26.7 \mathrm{~cm}$ ).

\section{Snowpack characteristics}

Draining lysimeters had much higher weight losses than contained ones. Meltwater percolated through the basal drain holes and was either absorbed into the snowpack or soil or became runoff (Fig. 5). Weight losses peaked in mid-afternoon each day but occurred throughout any $24 \mathrm{~h}$ period. Maximum mean weight loss occurred 9 May between 12:20 and 14:30 h and was $0.255 \mathrm{~g} \mathrm{~min}^{-1}$ in the ROW drained lysimeters. The highest weight loss from contained lysimeters was in the forest on the same day between 14:30 and 17:00 $\mathrm{h}$ and was $0.031 \mathrm{~g} \mathrm{~min}^{-1}$.

The average weight loss over the 5 to 9 May period was highest for the drained ROW sites, but very similar rates of loss $\left(0.0051 \mathrm{vs} 0.0047 \mathrm{~g} \mathrm{~min}^{-1}\right.$ for forest vs ROW respectively) occurred for the contained lysimeters regardless of their location (Fig. 6). Melting rates were therefore higher on the ROW sites but little difference in evaporation/sublimation rates was measured.

The weight loss due to evaporation/sublimation, percolation into the snow and runoff appears high for the last $2 \mathrm{~d}$ of the study (Fig, 5). However, this is not the cumulative loss for the entire site, the total snowpack loss from the study area would be low at this time since most of the snowpack had already disappeared. Thus the rate of ablation from the remaining snow patches declined somewhat over the study period but the total

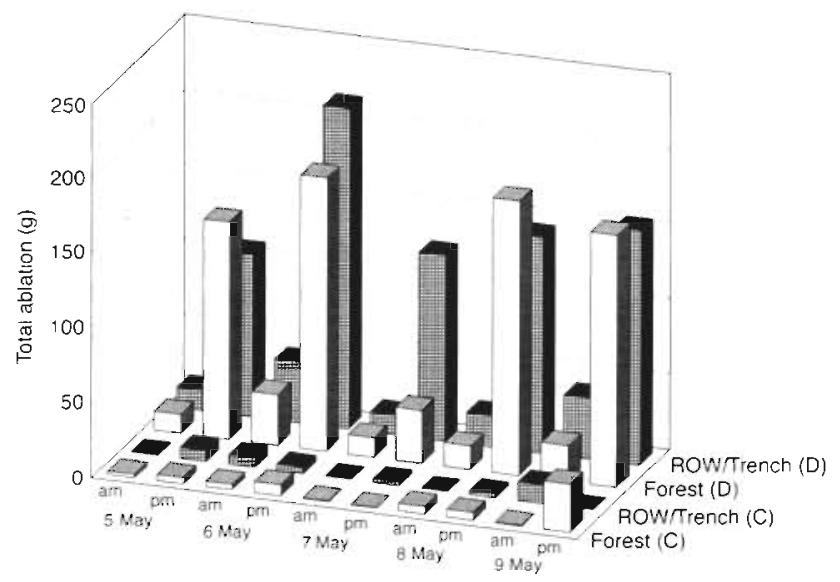

Fig. 5. Snowpack ablation over the study period (5 to 9 May). Diurnal changes in water loss relate to daily heating patterns. Drained lysimeters (D) had basal holes to permit the throughflow of meltwater whereas contained units (C) retained meltwater. Weight losses from contained cups represent the combined effects of sublimation and evaporation lost on the study site was only a fraction of the amount early in the experiment when the snowpack was more extensive and deeper.

Based on weight losses from draining lysimeters the potential maximum total ablation was estimated to be $30 \mathrm{~g} \mathrm{~cm}^{-2}$ (Fig. 7). This would be the case provided sufficient snow were on the site however, at a density of $337.8 \mathrm{~kg} \mathrm{~m}^{-3}$ there would have to have been $88.8 \mathrm{~cm}$ of snow and there clearly was not. The cumulative ablation calculation was based on the lysimeters that still occurred on snow during each sampling period. Lysimeters with high weight losses at the beginning of the sampling period would have been snow-free early, while those with lower rates would retain snow longer and provide data near the end of the monitoring period. Thus Fig. 7 can only be viewed as an idealized presentation of the potential cumulative ablation

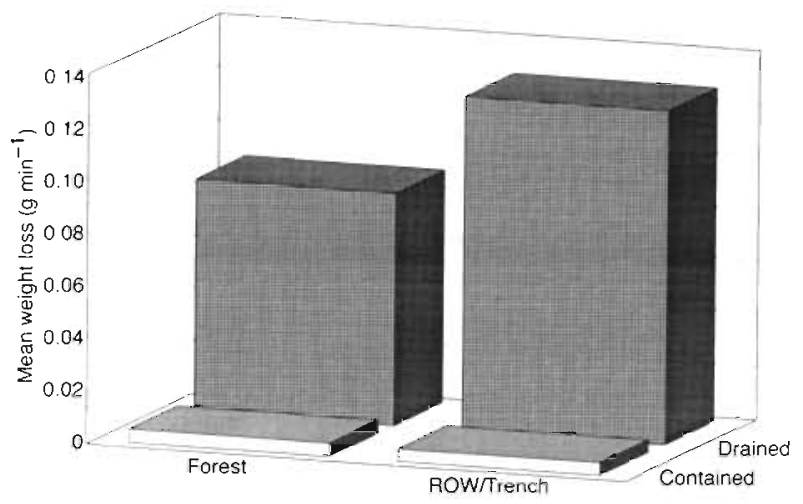

Fig. 6. Mean rate of snowpack ablation over the study period ( 5 to 9 May). The rate of snow loss in the forest was slower than on the ROW due to shading and lower wind speeds. Drained lysimeters had basal holes to permit the throughflow of meltwater whereas contained units retained meltwater

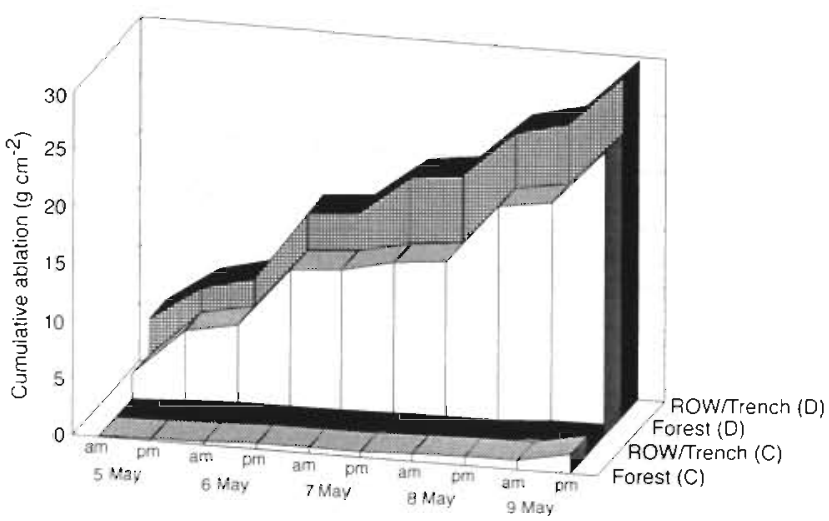

Fig. 7 Ablation of the snowpack totalled $30 \mathrm{~g} \mathrm{~cm}^{-2}$ over the study penod. The small amount that evaporated and sublimated [ROW/Trench plus Forest contained (C) values] suggests that the majority of the snowmelt water became runoff and/or soil storage 
Fig. 8. Runoff characteristics during the snowpack ablation and snowmelt period, 3 to 10 May. The trench subsurface discharge from 5 to 8 May was in error since the water at this time was circumventing the surface discharge weir; consequently it was combined with surface discharge to estimate the actual surface component in the ROW combined graph

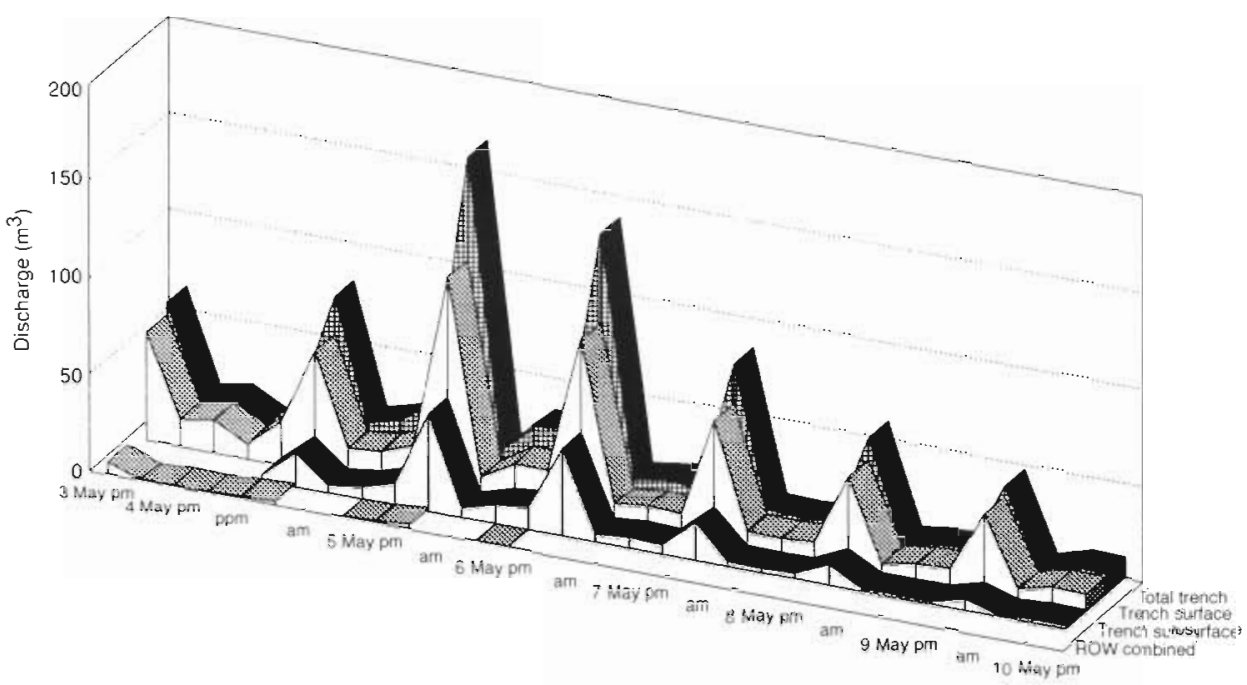

assuming sufficient snow was available. The actual cumulative ablation for the study area would lie between the extreme values of the draining and the contained lysimeters - in a range that is more realistic for the site (15 $\left.\mathrm{g} \mathrm{cm}^{-2}\right)$. Furthermore, water draining from upper portions of the snowpack probably refroze deeper in the snowpack and this would result in a higher ablation value when this snow was again used in the lysimeter later in the experiment period.

\section{Runoff}

The peak in runoff occurred on 5 May (Fig. 8). A very distinct diurnal pattern was apparent, especially early in the study period. With water flowing around the surface weir the values for subsurface discharge were in error for at least the 4 to 8 May period. By 9 May the surface runoff was captured by the weir and so the subsurface values at this time probably are accurate. On the ROW, discharge was restricted to the snowpack ablation period.

Peak in runoff coincided with the higher ablation rates early in the study (Figs. $5 \& 8$ ). However, with warmer temperatures later in the study the evaporation/sublimation rate was higher, thus reducing the amount of snowmelt available for runoff (Fig. 5).

\section{DISCUSSION}

\section{Snowpack persistence}

Over a period of $7 \mathrm{~d}$ (4 to 11 May) the forest snowpack went from almost $100 \%$ cover at an average depth of $40 \mathrm{~cm}$ to only isolated patches in remnant drifts along ROW edges. This rapid removal of the snowpack in spring is typical of Subarctic environments. The removal of the ROW snowpack was quicker, although late-lying drifts did occur. The ROW snowpack can be expected to be thinner due to deflation in winter (Kershaw 1991), and with a lower water equivalence it dissipates earlier than that of the forest. Running water on the trench and in seasonal drainage ways in the forest generally accelerates snowpack ablation in these localized areas except when it runs below drifts.

\section{Microclimate}

The cooler temperatures at the beginning of the study period reflect the presence of snow and ice at the surface of the ground or within the first few $\mathrm{cm}$ of the moss and organic surface layers (Fig. 2). In the forest and on the trench surface temperatures increased rapidly following snowmelt. On the trench, flowing snowmelt water kept ground surface temperatures close to freezing. The snow and surface water and ice depressed temperatures near the ground (i.e. at 0,10 and $50 \mathrm{~cm}$ ).

On the cleared ROW, the snowpack was at $50 \%$ when the study was initiated and this area had the highest thawing-degree-day totals. The higher heat units resulted from the early removal of the snowpack so that more energy was available to heat the ground surface layer and the air immediately above it (levels 10 and $50 \mathrm{~cm}$ on Figs. 2 \& 3). As the ground became exposed to produce the higher surface heating, the higher wind speed (Fig. 2) combined with the thinner snow on the ROW (Kershaw 1991) resulted in its becoming snow-free earlier 


\section{Depth of thaw}

The first measurement of thaw was near the end of the ablation study and at this time thaw had progressed to an average of $15.4 \mathrm{~cm}$ on the trench. Seven days later thaw on the trench had increased to $26.7 \mathrm{~cm}$, a rate of $1.62 \mathrm{~cm} \mathrm{~d}^{-1}$ (Fig. 4). If this rate of thaw was constant over the study then thaw on the trench would have been less than $9 \mathrm{~cm}$ on 4 May when the ablation study was initiated. This would be the maximum thaw depth since snow was covering the trench at the beginning of the study. Subsurface water flow was zero until the late evening of 4 May ('ppm' on Fig. 8), suggesting that thaw depth was too shallow to permit measurable throughflow.

Thaw on the ROW and trench would have been initiated at or just before dissipation of the snowpack, thus the deeper thaw layers reflect the longer time period during which thaw could occur. Thaw on the trench was greatest due to the lack of an insulating plant and organic layer cover (Fig. 4). In addition, the flowing water on the trench would provide heat to the ground and thus promote thaw. Finally, the deeper active layers on ROW and trench sites (Gallinger \& Kershaw 1988) at the end of the previous thaw season could have resulted in warmer soil temperatures at the beginning of the 1991 thaw season. Warmer soils would require less heating to induce thawing

The fine-grained sediments underlying the site (Evans et al. 1988) do not have a high infiltration capacity. Consequently, even with as much as $15 \mathrm{~cm}$ of thaw during the snowmelt runoff period it is unlikely that subsurface flow was a significant portion of the runoff (Fig. 8).

\section{Snowpack ablation}

The highest rates of weight loss occurred in mid- to late afternoon when daily warming was greatest and accumulated heat units were highest. While air temperatures dropped below $0^{\circ} \mathrm{C}$ at night it took time to warm the snow during the day to isothermal conditions (Male \& Gray 1981). Melt, sublimation and evaporation were greatest when the highest weight losses were recorded. As snow melted and the released water drained deeper into the snowpack it could have assisted in the heat transfer processes and accelerated ablation of the relatively shallow snowpack (Male \& Gray 1975). Near the end of the process, higher amounts of exposed bare ground, thinner snowpack and free water at the soil surface led to acceleration of ablation. Exposed ground would enhance heat transfer to the remaining snow by long-wave emissions and conduction (Male \& Gray 1981). A thinner snowpack permits more energy to penetrate to the ground where it can be absorbed by the soil or meltwater and then reradiated back to the snow (Male \& Gray 1981).

\section{Runoff}

Change in runoff reflected the ever diminishing source of water as the snowpack melted. Jordan's (1983) slope and snowpack depth were an order of magnitude greater than those of the SEEDS study area $\left(1.5^{\circ}\right.$ slope $)$ but he also found little infiltration of meltwater and little time lag between melt and runoff. As with Jordan (1983) distinct diurnal peaks were observed to closely follow melt and percolation of meltwater in the ablating snowpack for the 2 peak ablation days (5 and 6 May in Figs. 5 \& 8).

The relatively high rate of subsurface trench runoff early in the study was largely due to water circumventing the weir since at this time active layer development was virtually nil. Values of subsurface trench discharge for 10 May probably were realistic for that time and earlier values should be added to the surface discharge.

The lack of runoff from the ROW for the last $4 \mathrm{~d}$ of the study reflects the absorptive capacity of the largely intact moss, lichen and organic surface horizons in the soil. However the lower level of the trench would channel any near surface flow off of the ROW and it would be measured as surface trench flow. Thaw was minimal early in the study and soil water storage was therefore minimal. On the ROW, discharge could only be measured as the snowpack ablated and once it was gone or severely depleted, runoff ceased since water was absorbed by the vegetation and soil.

Peak in runoff coincided with the higher ablation rates early in the study (Figs. $5 \& 8$ ). However, with warmer temperatures later in the study the evaporation/sublimation rate was higher, thus reducing the amount of snowmelt available for runoff or soil storage (Fig. 5).

\section{CONCLUSIONS}

Higher air temperatures and higher wind speeds on the treeless ROW were more conducive to rapid dissipation of the snowpack than in the undisturbed forest. With a thinner snowpack the snowpack on the ROW became isothermal earlier than in the forest and once bare ground was exposed the rate of snowpack dissipation increased. Most snowpack ablation resulted in percolation of snowmelt into the snowpack and surface runoff. The lack of soil thaw combined with low infiltration capacities facilitated runoff rather than surface 
and subsurface storage. However, runoff differences between a mineral soil surface horizon (trench) and an organic/moss-lichen surface (ROW) may, in part, be attributed to storage differences. The majority of snowpack ablation and consequent snowmelt runoff occurred over a 4 d period.

Acknowledgements. Funding for this project came from Natural Sciences and Engineering Research Council, Canada, the Canadian Circumpolar Institute, Northern Oil and Gas Action Programme, Imperial Oil, the Royal Canadian Geographical Society and the University of Alberta. Much appreciated logistical support came from Interprovincial Pipe Lines Ltd. Craig Olsen, Dave Seburn and Kim Winnicky were albedo buddies in the data collection.

\section{LITERATURE CITED}

Adams WP, Findlay BF (1966) Snow measurement in the vicinity of Knob Lake, Central Labrador-Ungava, winter 1964-65. In: Proc. 23rd Annual Meeting of the Eastern Snow Conference, p 26-40

Adams WP, Rogerson RJ (1968) Snowfall and snowcover at Knob Lake, Central Labrador-Ungava. In: Proc 25th Annual Meeting of the Eastern Snow Conference, p $110-139$
Evans KE, Kershaw GP, Gallinger BJ (1988) Impacts of controlled surface disturbances on active layer and nearsurface permafrost in an homogeneous Picea mariana stand, Fort Norman, N.W.T., Canada. In: Senneset K (ed) Permafrost, Fifth International Conference Proceedings. Tapir, Trondheim, p 568-573

Gallinger BJ, Kershaw GP (1988) Active layer and geomorphological responses to human-induced disturbances on permafrost-affected terrain. BC Geogr Ser 46:23-38

Jordan P (1983) Meltwater movement in a deep snowpack, 1 Field observations. Water Resour Res 19(4):971-978

Kershaw GP (1991) The influence of a simulated transport corridor on snowpack characteristics, Fort Norman, N.W.T., Canada. Arct alp Res 23:31-40

Lewkowicz AG, French HM (1982) The hydrology of small runoff plots in an area of continuous permafrost, Banks Island, N.W.T. In: Proc Fourth Canadian Permafrost Conference, Calgary. Associate Committee on Geotechnical Research, National Research Council of Canada, Ottawa, p 151-162

Male DH, Gray DM (1975) Problems in developing a physically based snowmelt model. Can J civil Eng 2: $474-488$

Male DH, Gray DM (1981) Snowcover ablation and runoff. In: Gray DM, Male DH (eds) Handbook of snow, principles, processes, management and use. Pergamon Press, Toronto, p 360-436

Steer P, Woo M-K (1983) Measurement of slope runoff in a permafrost region. Can geotech J 20:361-365

Woo M-K, Heron R, Marsh P (1982) Basal ice in high Arctic snowpacks. Arct alp Res 14(3):251-260 